\title{
THE INFLUENCE OF JOB SATISFACTION AND ITS EFFECT ON EMPLOYEE TURNOVER INTENTION IN FINANCIAL SERVICE INDUSTRY OF MALAYSIA
}

\author{
Andrew Sija ${ }^{\mathrm{i}}$ \\ University College of Technology Sarawak, \\ School of Business Management, \\ Malaysia
}

\begin{abstract}
:
High employee turnover has a severe impact on financial service industry, both financially and emotionally. The financial service industries must take a step to recognize possible causes of turnover intention, measure the turnover rate, determine the turnover cost and address the turnover problems seriously. The aim of this study is to measure the determinants of job satisfaction and its effect on employee turnover intention in the financial services industry in Malaysia. In specific, it is to assess the relationships between the independent variables (compensation and benefit, employee recognition, supervision support and promotional opportunity) and employee turnover intention. A total of 127 feedbacks obtained from employees in four selected well-known banks in this study. The survey questionnaires were in the form of google form and were sent via email to the respective representative of the selected bank. The study used two types of data analysis and had identified five (5) hypotheses which were tested using statistical technique SPSS version 26. The descriptive analysis was used to gauge the respondent's demographic information such as gender, age, education level, bank served and tenure of services. Meanwhile the inferential analysis was mainly for examining the relationship between compensation and benefit, employee recognition, supervision support, promotional opportunity and employee turnover intention. The results revealed promotional opportunity is the strongest predictor in influencing employee turnover intention with unstandardized coefficients, $\beta=.673, t=7.016 p<.05$, followed by compensation and benefit with $\beta=.276, t=2.861, p<.05$. The most significant contribution of this study is that it explores for the first time the investigation of compensation and benefit with promotional opportunity affecting employee turnover intention in the most well-known and established banks in Malaysia. This study is hoping to contribute both on theoretical and practical value to the banks in maintaining their ranking, competitiveness and finding best solutions towards retaining talented employees.
\end{abstract}

JEL: J30; L20; L23

i Correspondence: email $\underline{\mathrm{dr} . r e w s @ y a h o o . c o m}$ 
Keywords: employee turnover intention, compensation and benefits, employee recognition, supervision support, promotional opportunity

\section{Introduction}

To the employees, intention to leave current organization is considered common phenomena among all employees who have been working for quiet long in one organization. This issue has become a trend in the job market whenever an employee moved and leave the current organization to the new organization as they feel motivated and more satisfy with the requirements and compensation offered at the new organization. However, to the employers of the current organization, the rise of turnover intention among employees is something that the current organization must seriously focus into. It's really need special attentions and tools since the impact of employee turnover intention could put the organization into a challenging situation particularly in maintaining the workforce and growth in the organization. The role of human capital development nowadays is more challenging and expanding to not only just taking care of the employees' welfare but would look into the development of the employees which includes career development, knowledge skills enhancement, professional development and competitive reward on their performance. Thus, it is very important for the employer to know and recognize the difference between employees who leave because they are unhappy and those who leave for other reasons. Referring to the report conducted by Hewit Associates (2009/2010) in their report found that the highest turnover rate was recorded by the financial services and high-tech / IT industry with $18.3 \%$ and $20 \%$ respectively. The total turnover rate in Malaysia has increased from $9.3 \%$ in year 2009 to $10.1 \%$ in year 2010. The main reasons for this were that employees have got better external opportunity $(67 \%)$ followed by limited growth opportunities $(46 \%)$ and some went for further studies (38\%). Another finding by Willis Towers Watson in 2013 shows that Malaysia's financial services industry has a greatly increasing turnover rate from $7.4 \%$ in 2012 to $13.3 \%$ in 2013. Alluded from the report, despite increase in salary, the turnover rate of employees in the banking industry in Malaysia remain high. Whilst Apadore and Ramasamy (2017) in their study has confirmed that the financial and banking sector is found to have the highest turnover rate with 18.3\%. Moreover, the Department of Labour of Peninsular Malaysia (2016) has reported 7,070 out of 14,138 of employees were voluntary terminated in the half year quarter of 2016. This was further reported by the Sun Daily Online (2016) that the total of 31,476 employees accounted for voluntary termination were under the Voluntary Separation Scheme (VSS) as they received better compensation. With this, it is clearly showing that the rise in turnover intention has greatly impacted the productivity, quality, trust among clients and profitability of the financial service industry due to the loss of skills and knowledge. A well-established bank should always put their employee's interest first and it is important for these banks to have the right and talented employee to be in their organization and to fit the roles assigned in order to ensure the banks continuously perform and stay competitive. Hence, 
the findings of this research definitely will help the human resource manager in the financial service industry to craft and design effective retention programs by understanding further the factors contribute the most to banking employee's job satisfaction and reasons for intention to leave. This at the end would create loyalty between employees and the organization, moreover, can improve the overall competitiveness of financial service.

\section{Literature Review}

\subsection{Employee Turnover Intention}

According to research that has been done by Cotton and Tuttle (1986), Tse and Lam (2008), the study of employee turnover has attracted many researchers for nearly 90 years. Most of the findings discovered that the turnover has given a serious impact to the organization (Abbasi and Hollyman, 2000; Watrous et al., 2006). The estimated visible costs of turnover which to be bear by the organization were approximately equaled to $\$ 11$ billion annually (Abbasi \& Hollman, 2006). Apart from financial cost effect, employee turnover has caused massive disruption of efficiency in the organization which include poor customer relations, decrease in morale of employees and declining in organizational performance (Abbasi \& Hollman, 2000; Watrous et al., 2006). According to many researchers, turnover can be categorized into voluntary and involuntary. Voluntary turnover refers to a process in which an employee makes a decision to stay or leave the organization (McPherson, 1976), and this is usually dysfunctional highly detrimental to the organization (Mobley, 1982). However, involuntary turnover was best referring to a process in which the organization assumes control over employee's decision to stay or leave (McPherson, 1976). In other words, this type of turnover involved removing and retrenchment of employees who were found to be not performing (Price, 1989) or involving in any misconduct (Bebe, 2016). Turnover intention refers to a process and willingness of leaving the current job and exist from the organization. It means whenever if the employees seriously have decided to leave the jobs, they have thought to have that intention to leave the current organization. Based on Fishbein and Ajzen (1975) study on attitudes-intentions-behavior model, they found that job satisfaction is likely to influences turnover intentions. They pointed out that attitudes toward the job impact the beliefs about the consequences or utility of leaving the organizations which ultimately leads to actual turnover behaviors.

\subsection{Compensation and Benefits}

Compensation can be best described as something that was received by employees in return of the service provided. It's refers to the benefits given to the employees in appreciation of the services rendered to the organization (Rifa'l et al, 2019). Chaudhry et al. (2011) added that salary is a kind of compensation for an employee by the organization. Organization can use salary as a reward and determinants in improving employee's motivation and confidence at work. Study shows that if the organization fails 
to pay an adequate and competitive salary, it will cause dissatisfaction among employees and will make employee leaving the organization (Lee \& Sabhrarwal, 2016). However, many employees will choose to work with the organization that offer them better compensation and benefit package (Sattar \& Ahmed, 2014). An excellence bank with remarkable reputation, achievement and brand is able to attract potential new employees because new employees could differentiate their organization from another and create a competitive advantage for organizations (Alder \& Chiselli, 2015). The willingness of employees to stay in the organizations was influenced by the amount of compensation and benefits paid to them (Johari, Yean, Adnan, Yahya \& Ahmad, 2012; Osibanjo, Adenjji, Falola \& Heirsmac, 2014). Yeo, Hadziroh and Tang (2020) investigated the determinants of turnover intention among bank employees in Kuala Lumpur. Their study shows that compensation and benefit have negative relationship with turnover intention. Based on this assertion, we formed a hypothesis statement as follows:

H1: Compensation and benefit has positively and significantly related to Employee Turnover Intention.

\subsection{Employee Recognition}

According to Maroudas et at., (2008), employee will feel demotivated if the organization they worked with has failed to set goals and didn't produce feedback and evaluation results. Following the report produced by Society of Human Resource Management (2012), they found that about 51 percent of supervisors stated they recognize employees who do a good job, however only 17 percent of the employees at the same organizations reported that their supervisors recognize them sufficiently. Rath and Cliton (2004), added that 65 percent of the workforce report receiving no recognition at work in the past 12 months. Meanwhile, research shows that non-financial factors are actually key to improving employee morale and motivation (Mercer, 2011). Moreover, a recent survey conducted by the Chicago Tribune of over 30,000 individuals found that the number one reason cited by employees who enjoy their work was: "I feel genuinely appreciated at this company" (Huppke, 2013). From these reviews, its shows that employee recognition plays an important role as a motivation factor in job satisfaction and turnover intention. Human resource managers can use reward and recognition as a tool (extrinsic and intrinsic) to motivate employees by recognizing and rewarding highly qualify and commendable employees (Hansen et al., 2002). The absence of these systems may increase turnover intention among employees (Urichuk, 1999). Based on the above, we found the possibility of relationships between employee recognition and turnover intention among employees. Therefore, the second hypothesis we developed was:

H2: Employee recognition is positively and significantly related to Employee Turnover Intention. 


\subsection{Supervision Support}

Mitchel et al. (2001) demonstrated the importance of supervisor / manager relationship in linking employees to their job and organization. Supervisor / managers support exist when employees in the organization was able to describe or perceive their supervisor / manager as good in developing people, leading them by example and giving them the full support in doing their job. Scholars found that employee job satisfaction and intention to leave organization have positively affected by supervisor's support and acknowledgement of employees (Yang, Brown \& Moon, 2011). The supervisors are representative for the company, if they are supportive and caring, employees recognize the company as the same. A finding by Collin (2018) proved that there is a negative relationship between supervision and employee turnover intention. This clearly shows that there is a need for supervisor / managers to provide encouragement, support and proper work guidance to the employees. According to Salleh, Niar and Harum (2012), the influence shown by the supervisor / managers would make employees feels loyal to them, psychologically attached and they are willing to remain with the supervisors / manager. Based the review above, we found the possibility of relationships between supervision support and employee turnover intention in the financial services industry. Therefore, our third hypotheses developed were:

H3: Supervision support is positively and significantly related to Employee Turnover Intention.

\subsection{Promotional Opportunity}

Pergamit and Veum (1999) initiated that a positive relationship between career development and job satisfaction which helps to retain employees. They further explained internal career development of employees is regarded the best forecaster of an employee's operative commitment. For most of the companies, they might have to think on providing promotional opportunity and future employment whenever they want to retain good professionals (Hassan, 2014). According to Tsigilis et al. (2006), Ellickson and Logsdon (2014), they described promotion was the second important attribute of job satisfaction and has a positive influence on job satisfaction. If the promotion policy is good, it will lead and encourage more commitment among employees (Naval \& Srivastava, 2004). Good promotion policies could increase status of the employee and personal growth, leads more responsibilities, increase in commitment and involvement (Naval \& Srivastava, 2004). Moreover, employee who are promoted on the basis of actual performance and achievement are found to be more satisfied with their career while those employees who were promoted on the basis of seniority are less satisfied with their jobs (Butt et al. 2007). The human capital development must be able to understand that employees are inspired by different set of needs. The career promotional opportunity is crucial for an employee to fulfill their self- esteem needs. By providing promotion, it can provide an opportunity to the employees for developing their skills and gain access to new positions (Hofhuis et al., 2014). In doing so, the human capital development in the companies is encouraged to design fair career development programs and procedures 
based on employee's requirements as well as the competencies and aspiration of the employees (Collin, 2018). Based on this assertion, we managed to construct two hypotheses which were:

H4: Promotional Opportunities is positively and significantly related to Employee Turnover Intention.

H5: Promotional Opportunities offered is most likely to be the strongest predictor of Employee Turnover Intention.

\section{Material and Methods}

\subsection{Population and Sample}

This study is conducted on banking employees in four selected well-known banks namely Maybank Bhd, CIMB Bank Bhd, Public Bank Bhd and RHB Bank Bhd. All of these four banks were located in Sarawak. The reasons to choose these four banks as the target population were due to their ranking and popularity. For this study, non-probability sampling was used to gather the data and the execution of convenient random sampling method was applied due to the fact that the method is easy, save time and economical to obtain responses in large populations. The total targeted population of this study is within 180 employees and a total of 127 respondents have responded to the questionnaires. The assurance of challenge size was founded on Krejcie and Morgan's table where a sample size of 127 is acceptable as where the given population of 180, a sample size of 123 would be needed to represent a cross-section of the population. Due to some restriction movement imposed by the government on Covid-19 pandemic, the closed -ended questionnaire is preferred and has been created using google forms. The data were collected through distribution of the survey questions in the google form (link given) via email to the representatives of the respective banks.

\subsection{Measurement Instrument}

Researcher has used quantitative approach and assisted by SPSS version 26 for data analysis. Questionnaires' design is vital became the key component and it must be concise and unambiguous (Hair, Money, Samouel \& Page, 2007). Survey questionnaires have been created using google forms and emailed directly to the respective representatives of the four selected well-known banks in East Malaysia. Prior to that, the researcher personally approached the commercial banks and shared with the representatives of each bank the objective and motives of the study. The questionnaires were divided into three sections. Section A is demographic factors, section B evaluates the employee's level of satisfaction in their current designation/position within their own banks they served while section $C$ contains questions on the respondents' desire to remain serving the banks. For section A, a set of nominal scale questions has been developed for identifying respondent's profile and demographic data which including gender, age, education, bank served, designation and tenure of banking experiences. For section $\mathrm{B}$ and $\mathrm{C}$, a total 
of 20 measurement items were used and measured using 5-point Likert Scale. It used to determine whether respondents are agreed with the question asked.

\section{Results and Discussion}

\subsection{Reliability Analysis}

In this study, the researcher has used reliability analysis to measure the consistency and stability of data with more generalisability of results obtained from survey questionnaires. According to Zikmund et al. (2009), the value of Cronbach's Alpha should be at least or larger than $0.700(\geq 0.700)$. Table 1 presents the result of the reliability test with the value of Cronbach's Alpha for all five variables shows high reliability. The value shows the questionnaire was reliable as the closer the value to 1 , the reliable the questionnaire. The questionnaire shows a high reliability based on the alpha score ( $\alpha=0.863-0.901)$. Furthermore Pallant (2010) stressed that an alpha score above 0.75 is generally indicating a scale of high reliability. Hence, it is concluded that all the five variables have reliability and acceptable for further analysis.

Table 1: Cronbach's Alpha reliability test

\begin{tabular}{|l|c|c|}
\hline Variable & No of items & Cronbach's Alpha $(\alpha)$ \\
\hline Compensation \& Benefit & 4 & .879 \\
\hline Employee Recognition & 4 & .901 \\
\hline Supervision Support & 4 & .879 \\
\hline Promotional Opportunity & 4 & .863 \\
\hline Employee Turnover Intention & 4 & .892 \\
\hline
\end{tabular}

Source: Author.

\subsection{Frequency Analysis}

Table 2 shows the distribution of respondents' profile in terms of gender, age, educational level, designation, banks served and tenure/year of working experiences. The gender wise distribution of the respondents reveals that 127 respondents, 57 (44.9\%) are males and $70(55.1 \%)$ are females. Age wise categorization of the respondents reveal that there were $17(13.4 \%)$ respondents fall in the age group of 18-24 years old, 41 (32.3\%) belong to age group 25-34 years old, 39 (30.7\%) between 35-44 years old, 27 (21.3\%) are in the age group of $45-54$ years old and $3(2.4 \%)$ belong to the age group of 54 and above. In terms of educational level, indicates that overall, the respondents are highly educated. A large number of respondents i.e. $77.9 \%(40.9 \%+37 \%)$ are graduates with STPM/Diploma and Degree qualifications. The SPM/Certificate holders were represented by $21.3 \%$ whilst the remaining $0.8 \%$ comprised of others qualification. Designation wise distribution of the respondents indicates that majority of respondents i.e. 52 (40.9\%) were from clerical, followed by the manager/HOD with 41(32.3\%), while the remaining 34 (26.8\%) were represented by officer / executive. For the institution profile, Maybank Bhd, Public Bank Bhd, RHB Bank Bhd and CIMB Bank Bhd were represented with the total of $32.3 \%, 29.1 \%$, $22.0 \%$ and $16.5 \%$ respectively. The review result of tenure/years of working experience 
displayed that most of the respondents (29.9\%) have been working for more than 15 years, followed with a figure of $29.1 \%$ was for those having been worked for 6-10 years, $21.3 \%$ were who have been working for $11-15$ years and $19.7 \%$ for those serving for $1-5$ years.

Table 2: Demographic profile of employees

\begin{tabular}{|c|c|c|c|c|c|}
\hline Category & Frequency & $\%$ & Category & Frequency & $\%$ \\
\hline \multicolumn{3}{|l|}{ Gender } & \multicolumn{3}{|l|}{ Education level } \\
\hline Male & 57 & 44.9 & SPM / certificate & 27 & 21.3 \\
\hline Female & 70 & 55.1 & STPM / Diploma & 52 & 40.9 \\
\hline \multicolumn{3}{|l|}{ Age } & Degree & 47 & 37.0 \\
\hline $18-24$ years & 17 & 13.4 & Other & 1 & 0.8 \\
\hline $25-34$ years & 41 & 32.3 & \multicolumn{3}{|l|}{ Banking Served } \\
\hline $35-44$ years & 39 & 30.7 & CIMB Bank Bhd & 21 & 16.5 \\
\hline $45-54$ years & 27 & 21.3 & Maybank Bhd & 41 & 32.3 \\
\hline 54 years \& above & 3 & 2.4 & Public Bank Bhd & 37 & 29.1 \\
\hline \multicolumn{3}{|l|}{ Designation } & RHB Bank Bhd & 28 & 22.0 \\
\hline Clerical & 52 & 40.9 & \multicolumn{3}{|l|}{ Tenure } \\
\hline Officer / Executives & 34 & 26.8 & $1-5$ year & 25 & 19.7 \\
\hline \multirow[t]{3}{*}{ Manager / HOD } & 41 & 32.3 & $6-10$ years & 37 & 29.1 \\
\hline & & & $11-15$ years & 27 & 21.3 \\
\hline & & & Above 15 years & 38 & 29.9 \\
\hline
\end{tabular}

\subsection{Factor Analysis}

Factor analysis has been applied to the perception of 127 respondents regarding 20 variables statements measured on a five-point Likert scale. This is done with the idea of simplifying complex and diverse relationship that could exist among a set of observed variables by exploring common factors that link together the apparently unrelated variables and provide insight into the structure of the data. In testing whether factor analysis was appropriate for the variables construct, Kaiser-Meyer-Olkin (KMO) and Bartlett's test were first conducted, followed by extraction communalities, factor loading, eigenvalues and scree plot. The KMO measures the magnitude of observed correlation coefficients to the magnitude of partial correlation coefficients. According to Malhotra (2008), a value $>0.5$ is desirable. The results are shown in Table 3 below:

Table 3: Summary of factor analyses

\begin{tabular}{|l|c|c|c|c|c|c|}
\hline Variables & $\begin{array}{c}\text { Item } \\
\text { loading }\end{array}$ & $\begin{array}{c}\text { Eigen } \\
\text { value }\end{array}$ & $\begin{array}{c}\text { \% of variation } \\
\text { explained }\end{array}$ & KMO & BTS & $\begin{array}{c}\text { p- } \\
\text { value }\end{array}$ \\
\hline Compensation \& Benefit & $.799-.853$ & 2.762 & 69.04 & .795 & 211.594 & $.001^{*}$ \\
\hline Employee Recognition & $.565-.869$ & 2.325 & 58.13 & .645 & 158.833 & $.001^{*}$ \\
\hline Supervision support & $.840-.910$ & 3.131 & 78.27 & .847 & 330.550 & $.001^{*}$ \\
\hline Promotional Opportunity & $.826-.873$ & 2.933 & 73.33 & .819 & 258.857 & $001^{*}$ \\
\hline $\begin{array}{l}\text { Employee Turnover } \\
\text { Intention }\end{array}$ & $.824-.915$ & 2.996 & 74.88 & .824 & 285.395 & $.001^{*}$ \\
\hline${ }^{*} p<.05$ & & & & & & \\
\hline
\end{tabular}


As can be seen from Table 3 above, the KMO value is greater than .05 and the significant value, $\mathrm{p}<.05$ which shows that the $\mathrm{KMO}$ value is significant. This means the factor analysis is appropriate. To interpret the factor loadings, a value +.50 or greater is considered significant; loading or +.40 are considered more important; loading of +.30 are considered significant (Hair et al., 2006). Due to large factor loading ranging from the lowest of .565 to the highest of .915 while performing extraction of communalities, hence indicates that all 20 items in the variables is explained by the factors and correlated very significantly to the factor itself. The percentage of variance for all variables used in this study were explained through from $58.13 \%$ to $78.27 \%$ of the factor. Moreover, the eigenvalue of all variables in this study were exceeded 1, proved that the analysis of scree plot for all variables goes steeply downward from the first to the last factor, this concluded that all of the items used in the variables reached statistical significance and supporting the factorability of the correlation matrix.

\subsection{Pearson Correlation}

From Table 4 below, the relationship of each independent variable with employee turnover intention is $\mathrm{r}=.631$ for compensation and benefit, $\mathrm{r}=.503$ for employee recognition, $r=.636$ for supervision support and $r=.765$ for promotional opportunity. The Pearson correlation analysis results shows positive relationship on the four independent variables. Thus, indicating that there were statistically significant correlated with banking employee turnover intention (dependent variable). Therefore, hypotheses 1, 2, 3 and 4 were accepted. There is a significant relationship between compensation and benefit with banking employee turnover intention, $r=.631$, employee recognition and employee turnover intention, $r=.503$, supervision support, $r=.636$ and promotional opportunities and employee turnover intention, $r=.765(p<.05)$. Promotional opportunities were found to be the most significant and highly correlated to employee turnover intention.

Table 4: Pearson correlation analysis between variables studied

\begin{tabular}{|l|c|c|c|c|c|}
\hline Variable & ETI & CB & ER & SS & PO \\
\hline \multicolumn{5}{|l|}{} & \multicolumn{5}{|c|}{$\boldsymbol{R}$} & & \\
\hline ETI & $\mathbf{1}$ & & & & \\
\hline CB & $.631^{*}$ & 1 & & & \\
\hline ER & $.503^{*}$ & $.710^{*}$ & 1 & 1 & \\
\hline PO & $.636^{*}$ & $.736^{*}$ & $.579^{*}$ & $.759^{*}$ & 1 \\
\hline
\end{tabular}

Note: $\mathrm{ETI}=$ Employee Turnover Intention, $\mathrm{CB}=$ Compensation and Benefit, ER = Employee Recognition, $\mathrm{SS}=$ Supervision Support, $\mathrm{PO}=$ Promotional Opportunity

${ }^{*}$ correlation is significant at $.05(p<.05)$. 


\subsection{Multiple Regression Analysis}

The result in Table 5 shows the relative contribution of each of the Compensation and Benefit, Employee Recognition, Supervision Support and Promotional Opportunity to the variance in the Employee Turnover Intention. Compensation and benefit, and promotional opportunity contributed significantly to Employee Turnover Intention (Compensation and benefit, $\beta=.276, t=2.861, p<.05$ and Promotional opportunity, $\beta=$ $.673, t=7.016 p<.05)$, except Employee recognition and Supervision support $(p>.05)$. The Unstandardized Coefficients B column gives the coefficients of the independent variables in the regression equation including all the variables. The Standardized Coefficients $(\beta)$ show that promotional opportunity has the largest absolute value of .673 , followed by compensation and benefit with .276, -.154 on employee recognition and supervision support with .011. This shows the amount of unique variance on predictor account was statistically significant. Since the amount of promotional opportunity was significant, it accounts for significant amount of unique variance in employee turnover intention. The amount of variance of promotional opportunity scored, was explained in employee turnover intention unique to itself significantly, which means it explained something deepen in employee turnover intention than other three independent variables didn't explain. This suggests that promotional opportunity is the strongest predictor of employee turnover intention. Thus, hypothesis 5 is accepted. Promotional Opportunities offered is most likely to be the strongest predictor of Employee Turnover Intention among employees in that four selected mega banks.

Table 5: Relatives Contribution of Compensation and Benefit, Employee Recognition, Supervision Support, Promotional Opportunity (independent variables) and Banking Employee Performance (dependent variable)

\begin{tabular}{|c|c|c|c|c|c|c|}
\hline \multirow{2}{*}{\multicolumn{2}{|c|}{ Model }} & \multicolumn{2}{|c|}{$\begin{array}{c}\text { Unstandardized } \\
\text { Coefficients }\end{array}$} & \multirow{2}{*}{$\begin{array}{c}\begin{array}{c}\text { Standardized } \\
\text { Coefficients }\end{array} \\
\text { Beta }(\beta) \\
\end{array}$} & \multirow[t]{2}{*}{$\mathbf{t}$} & \multirow[t]{2}{*}{ Sig. } \\
\hline & & B & Std. Error & & & \\
\hline \multirow[t]{5}{*}{1} & (Constant) & .713 & .362 & & 1.969 & $.051^{*}$ \\
\hline & Compensation \& Benefit & .341 & .119 & .276 & 2.861 & $.005^{*}$ \\
\hline & Employee Recognition & -.231 & .129 & -.154 & -1.792 & .076 \\
\hline & Supervision Support & .001 & .097 & .011 & .115 & .909 \\
\hline & Promotional Opportunity & .704 & .100 & .673 & 7.016 & $.000^{*}$ \\
\hline
\end{tabular}

*significant level is at $.05(p<.05)$.

The overall regression model summary in Table 6 is statistically significant, with $\mathrm{F}(4,122)$ $=49,52$. The $\mathrm{p}$-value is less than 0.001 , with R-Squared equal to 0.619 , represents the value of 0.787 which explained that $78.7 \%$ of the variation in this model was able to be explained by all the independent variables whereas the remaining $21.3 \%$ was unexplained. Therefore, it can be concluded that among four independent variables, promotional opportunity account the most influential role in deriving employee turnover intention. This was supported based on the highest $t$-value and beta score as compared to other independent variables used in this study. 
Table 6: Model Summary of correlation between Compensation and benefit,

Employee Recognition, Supervision Support, Promotional Opportunity (independent variables) and Employee Turnover Intention (dependent variable)

\begin{tabular}{cccccccc}
\hline Model & $\mathbf{R}$ & $\mathbf{R}^{2}$ & Adjusted $\mathbf{R}^{2}$ & $\begin{array}{c}\text { Std. Error of } \\
\text { the Estimate }\end{array}$ & $\boldsymbol{R}^{2}$ change & $\boldsymbol{F}$ change & Sig. \\
\hline 1 & $.787^{a}$ & .619 & .606 & .417 & .619 & 49.518 & .000 \\
\hline
\end{tabular}

a. Predictors: (Constant), Compensation and Benefit, Employee Recognition, Supervision Support, Promotional Opportunity

b. Dependent variable: Employee Turnover Intention

\subsection{Discussion}

The main aim of this study is to gauge the relationship among all predictors used for job satisfaction and measure the effect on dependent variable i.e. the employee turnover intention through their level of significant. The findings indicated from Pearson Correlation Analysis shows that promotional opportunity is the most strongest construct with the significant value of $p=0.765(p<.05)$ that influence employees intention to leave banking. To explore further, multiple regression analysis has been applied and four factors emerged significant from factor analysis. These four factors, namely compensation and benefit, employee recognition, supervision support and promotional opportunity were statistically significant in the model at 5 percent level of significance. Referring to "B" values for all the variables, it can be seen that two factors are the most positively related to the employee turnover intention. Looking at the standardized $\beta$ values it can be concluded that promotional opportunity has the maximum effect on the overall employee turnover intention followed by compensation and benefit. The results of these two most influential factors were supported by the findings from past researchers such as Boudrea (1998) who stated that decision of employee to leave or stay is influenced by career development which referring to the promotional opportunity. Another study by Weng and Xi (2010) revealed that employee turnover intention was also significant influenced by career development. Furthermore, Ballout (2009) in his research on bank employees in Lebanon has suggested to the bank to provide an opportunity for career development to those highly committed and experienced employees due to the fact that high chances for these group of employees seriously seeking a career promotional opportunity. He reiterates any banks that could offer and provide long term career development would gain benefits from their employees. Aside to this, Collin (2018) in his study on the influence of job satisfaction on employee turnover intention in the manufacturing industry in Malaysia also found that career development of job satisfaction contributed most significantly to employee turnover intention.

The second influential factors i.e. compensation and benefit has significantly affecting employee turnover intention. This was supported by the study from Emiroglu, Tanriverdi \& Akova (2015), which the researchers found that employee will leave the organization if they found a mismatch between the job and reward. Another study proved by Kanwal and Tariq (2016) on the reward that make employee feel motivated, committed and work harder. Hence, by looking into the overall results of this study, we 
found that the result is consistent with other researcher's findings which described promotional opportunity, compensation and benefit were significant with employee turnover intention. From this study, it also signifies that employees who get a change of being promoted and get high compensation and benefits will possibly remain in the organization for a longer period compared to those employees who don't get promoted and earn lower compensation benefits.

With regards to high turnover costs, competition in workforce, inadequate supply of skills and technology changes in the financial service industry, career development become dominant and vital in human resource planning (Walker, 1980). Human resource planning in the financial service industry should focus on employee's development and one of it was career promotional opportunities. Having said that, if the employees were cultivated, they would become more productive and committed on his /her new roles towards organizational effectiveness. According to Baruch (2004), he found out employees have moved away from providing secure employment for all in providing opportunities for employee's development. Additionally, through promotional opportunities and effective career development pathway would provide employees with valuable knowledge and proficiency at the work place (Khan, Rajasekar, \& Al-Asfour, 2015). Therefore, it is the responsibility of the financial services companies to have an effective career development programs based on the needs of their employees.

\section{Conclusion and Recommendations}

This study provides immense implication and incredible findings to the selected wellknown banks. Firstly, the study provides theoretical and practical contribution. It contributes to the understanding of the factors that affect employee turnover intention in the financial service industry in Malaysia. Moreover, the study was conducted on the four selected well-known banks (Maybank Bhd, CIMB Bank Bhd, Public Bank Bhd and RHB Bank Bhd) with all of these banks were having high ranking and popularity among banking customers. By gauging their employees' level of loyalty could make banks reputation increased particularly when the banking customers experiencing the valuable support and quality services offered by banks employees who were very desire, skillful and talented. Based on this study, it proved that promotional opportunity regarded the strongest predictor for employee turnover intention among employees in these four banks. This result has supported the findings on the manufacturing industry of Malaysia done by Collin (2018) in which he found that career development was the most significant impact of job satisfaction on employee turnover intention. He suggested that the company should offer an opportunity for career development and develops fairer career development procedures. Hence, for the human resource managers in such well-known banks, it is important for them to maintain highly qualify and loyal staff through effective design of career development promotional plan in order to enhance their employee's job satisfaction, trust and retention. The next implication as revealed by this study was the impact of compensation and benefits on banking employee's turnover intention, which 
was relevant if measured by itself, although it may not so significant compared to the variable i.e. promotional opportunity used in this study. However, according to Kumar (2016), in his study on public banking sector in India found that there is a strong connection between compensation and benefits on job satisfaction. This again was supported by Lee and Sabharwal (2016) where they found that higher salary will lead to higher job satisfaction. Hence, it is critical for the financial service industry like banks to observe the relationship i.e. between promotional opportunity, compensation and benefit with job satisfaction and its influence on the employee turnover intention. By doing so, it could help the financial service industry to come up with new framework on how to increase the loyalty of their employee toward them. A new reform on the salary package, bonus structures and other benefits may be needed in order to make financial service industry become more competitive and towards at the end can eradicate the feeling of dissatisfaction towards job and intention to leave.

\subsection{Future Research Direction}

Some potential limitations discovered on this study which includes the sample used from only four selected well-known banks in Sarawak. Thus, the findings is not be generalized across all banking employees in Malaysia. Secondly, there might be reliability and validity issue with the information obtained from the questionnaires used i.e. via google form and were emailed to the representatives of each banks and the researcher has ignored those respondents that refuse to answer the questionnaires. The researcher suggested that more study to be conducted on employee turnover intention and measure the effect on different facet of organizational management such as productivity and human resource planning.

\section{Conflict of Interest}

The author can assure, confidently express that no conflicts of interest possibly linked with this research, and there has been no significant financial aid received for this study, authorship and publication that could have influenced the study's outcome. The author affirms that this research is original and has not been published in the past or elsewhere.

\footnotetext{
About the Author

Andrew Sija is a lecturer at University College of Technology Sarawak, Malaysia. He currently holds a Doctorate Degree in Business Administration, a Certified Trainer in Business Accounting, PSMB (Malaysia) and a Certified Instructor on Accounting for Hospitality Industry, AHLEi (USA). His research interest is on accounting, banking, education and business management.
} 


\section{References}

Abbasi, S. M. and Hollman, K. W. (2000). Turnover: the real bottom line. Public Personnel Management, 29, 333-42.

Adler, H. \& Ghiselli, R. (2015). The importance of compensation and benefits on university students' perception of organizations as potential employers. Journal of Management and Strategy, 6(1), 1-9

Ballout, H. I. (2009). Career commitment and career success: Moderating role of selfefficacy. Career Development International, 14(7), 655-670.

Bebe, I. A. (2016). Employee Turnover Intention in the U.S Fast Food Industry.

Boudrea, J. W. (1998). Strategic human resource management measures: Key linkages and the people vantage model. Journal of Human Resource Costing $\mathcal{E}$ Accounting, 3(2), 21-40.

Butt, B. Z., Kashif-Ur-Rehman \& Safwan, N. (2007). A study measuring the effect of pay, promotion and training on job satisfaction in Pakistan services industry. European Journal of Social Sciences, 5(3), 36-44.

Chaudhry, M. S., Sabir, H. M., Rafi, N., \& Kalyar, M. N. (2011). Exploring the relationship between salary satisfaction and job satisfaction: A comparison of public and private sector organizatios. The Journal of Commerce, 3(4), 1-14

Collin, L. C. (2018). The influence of job satisfaction on employee turnover intention in the manufacturing industry of Malaysia. Journal of Arts E Social Sciences, 1(2), 5363.

Cotton, J. L. and Tuttle, J. M. (1986). Employee turnover: a meta-analysis and review with implications for research. Academy of Management Review, 11, pp. 55-70

Emiroglu, B. D., Tanriverdi, H. \& Akova, O. (2015). The relationship between turnover intention and demographic factors in hotel business: a study at five star hotels in Istanbul. Procedia- Social and Behavioural Sciences, 207,385-397.

Fishbein, M. and Ajzen, I. (1975), Belief, Attitude, Intention, and Behavior: An Introduction to Theory and Research, Addison-Wesley, Reading, MA

Hair, J., Money, A., Samouel, P., \& Page, M. (2007). Research methods for business. John Wiley and Sons, Ltd.

Hansen, F., Smith, M., \& Hansen, R. (2002). Reward and recognition in employee motivation. Compensation and Benefit Review, 34(5), 64-72.

Hassan, R. (2014). Factors influencing turnover intentions among technical employees in information technology organization: A case of $\mathrm{XYZ}(\mathrm{M})$ SDN BHD. International Journal of Arts and Commerce, 3(9), 120-137.

Hofhuis, J., Van der Zee, K. I. \& Otten, S. (2014). Comparing antecedents of voluntary job turnover among majority and minority employees. Equality, Diversity and Inclusion: An International Journal, 33(8), 735-749.

Huppke, R. (2013). “Chicago's top workplaces: it's not about the gravy," Chicago Tribune, 11 November, available at: http://articles.chicagotribune.com/2013-11- 
12/business/ct-biz-tw-assurance-benefits-201311 121 gravy-workplaces-benefits (accessed 29 April 2021).

Johari, J., Yean, T. F., Adnan, Z., Yahya, K. K., \& Ahmad, M. N. (2012). Promoting employee intention to stay: Do human resource management practices matter? International Journal of Economics and Management, 6(2), 396-416.

Kanwal, B., \& Tariq, A. (2016). Organizational environment, job satisfaction and career growth opportunities: a link to employee's turnover intentions in University of Sargodha, Pakistan. Journal of Resources Development and Management, 20(1), 8-14.

Khan, S. A., Rajasekar, J., \& Al-Asfour, A. (2015). Organizational career development practices: Learning from an Omani Company. International Journal of Business and Management, 10(9), 88-98. doi: 10.5539/ijbm.v10n9p88

Kumar, R. (2016). The impact of personal variables on job satisfaction: A study of public sector bank employees in India. IUP Journal of Organizational Behaviour, 15(3), 40.

Lee, Y. J., \& Sabharwal, M. (2016). Education- Job match, salary, and job satisfaction across the public, non-profit, and for profit-sectors: Survey of recent college graduates. Public Management Review, 18(1), 40-64. https://doi.org/10.1080/14719037.2014.957342

Maroudas, L., Kyariakidou, O., \& Vacharis, A. (2008). Employees' motivation in the luxury hotel industry: the perceived effectiveness of human resource practices. Managing Leisure, 13(3-4), 258-271.

McPherson, B. D. (1976). Involuntary turnover and organizational effectiveness in the National Hockey League, in Gruneau, R.S. and Albinson, J.G. (Eds), Canadian Sport: Sociological Perspectives, Addison-Wesley, Don Mills, pp. 259-75.

Mercer (2011), "Guide for employers," available at: http://www.mercer.com/pressreleases/1430455 (accessed 1 May 2021).

Mitchell, T. R., Holtom, B. C., Lee, T. W., Sablynski, C. J., \& Erez, M. (2001). Why people stay?: using job embeddedness to predict voluntary turnover. Academy of Management Journal, 44(6), 1102-21.

Mobley, W. H. (1982), Employee Turnover, Causes, Consequences, and Control, Addison-Wesley, Reading, MA.

Naval, B. \& Srivastava, D. (2004). Sectorial comparison of factors influencing job satisfaction in Indian banking sector. Singapore Management Review, 26(2), 89-99.

Osibanjo, A. O., Adeniji, A. A., Falola, H, O. \& Heirsmac, P. T. (2104). Compensation package: a strategic tool for employees' performance and retention: Leonardo Journal of Sciences, 25, 65-84.

Pallant, J. (2010). SPSS Survival Manual (4th ed.). McGraw-Hill Education. USA.

Pergamit, M. R., \& Veum, J. R. (1999). What is a promotion? Industrial and Labor Relations Review, 52(4), 581.

Price, J. L. (1989). The impact of turnover on the organization. Work and Occupations, 16, 461-73.

Rifa'I, M. N., Sukidio So, \& Efendi, R. (2019). The Performance of Employees Influenced by Leadership Styles and Compensation. International Journal of Multicultural and 
Multireligiuos Understanding, 6(6), 581-587. Retrieved from https://doiorg.newdc.oum.edu.my/10.18415/ijmmu.v616.1243

Salleh, R., Niar, M. S., \& Harum, H. (2012). Job satisfaction, organizational commitment, and turnover intention: A case study on employees of a retail company in Malaysia. International Journal of Social, Behavioural, Educational, Economic, Business and Industrial Engineering, 6(12), 3429-3426.

Sattar, S. \& Ahmed, S. (2014). Factors effecting employee turnover in banking sector. Developing Country Studies, 4(3), 110-115.

Society for Human Resource Management (2012), "SHRM winter 2012 report," available at: http://go.globoforce.com/rs/globoforce/images/SHRMWinter2012Report.PDF (accessed 1 May 2021).

Tse, H. H. M. and Lam, W. (2008). Transformational leadership and turnover: the roles of LMX and organizational commitment. Academy of Management Proceedings, Anaheim, CA, 8-13 August, pp. 1-6.

Urichuk, B. (1999). Employee recognition and praise. The Canadian Manager, 24(2), $27-29$.

Walker, J. W. (1980). Human resource planning. New York: Grolier, Inc.

Watrous, K. M., Huffman, A. H. and Pritchard, R. D. (2006). When coworkers and managers quit: the effects of turnover and shared values on performance. Journal of Business and Psychology, 21, pp. 103-26.

Yang, S., Brown, G. C., \& Moon, B. (2011). Factors leading to correction officer's job satisfaction. Public Personnel Management, 4(4), 22-38.

Yeo, C. H., Ibrahim, H., \& Tang, S. M. (2020). The determinants of turnover intention among bank employees. Journal of Business and Economic Analysis, 3(1), 42-54. Doi: https://doi.org/10.36924/sbe.2020.3103

Zikmund, W. G., Babin, B. J., Carr, J. C., \& Griffin, M. (2009). Business research methods (8 $^{\text {th }}$ ed.). New Castle: South-Western College Pub. 
Creative Commons licensing terms

Authors will retain copyright to their published articles agreeing that a Creative Commons Attribution 4.0 International License (CC BY 4.0) terms will be applied to their work. Under the terms of this license, no permission is required from the author(s) or publisher for members of the community to copy, distribute, transmit or adapt the article content, providing a proper, prominent and unambiguous attribution to the authors in a manner that makes clear that the materials are being reused under permission of a Creative Commons License. Views, opinions and conclusions expressed in this research article are views, opinions and conclusions of the author(s). Open Access Publishing Group and European Journal of Economic and Financial Research shall not be responsible or answerable for any loss, damage or liability caused in relation to/arising out of conflict of interests, copyright violations and inappropriate or inaccurate use of any kind content related or integrated on the research work. All the published works are meeting the Open Access Publishing requirements and can be freely accessed, shared, modified, distributed and used in educational, commercial and non-commercial purposes under a Creative Commons Attribution 4.0 International License (CC BY 4.0). 